\title{
Worlding the Study of Normative Power: Assessing European and Chinese Definitions of the "Normal"
}

\author{
Emilian KAVALSKI \\ Li Dak Sum Chair Professor of China-Eurasia Relations and International Studies \\ University of Nottingham Ningbo
}

\section{Young Chul CHO}

Assoc. Prof. Dr., School of International Studies, Chonbuk National University

To cite this article: Kavalski, Emilian and Cho, Young Chul, "Worlding the Study of Normative Power: Assessing European and Chinese Definitions of the "Normal", Uluslararasi İliskiler, Vol. 15, No. 57, 2018, pp. 49-65, DOI: 10.33458/uidergisi.518042

To link to this article: https://dx.doi.org/10.33458/uidergisi.518042

Submitted: 16 October 2017

Printed Version: 01 March 2018

\section{Uluslararası İlişkiler Konseyi Derneği | International Relations Council of Turkey \\ Uluslararası İlişkiler - Journal of International Relations \\ E-mail : bilgi@uidergisi.com.tr}

All rights of this paper are reserved by the International Relations Council of Turkey. With the exception of academic quotations, no part of this publication may be reproduced, redistributed, sold or transmitted in any form and by any means for public usage without a prior permission from the copyright holder. Any opinions and views expressed in this publication are the author(s)'s and do not reflect those of the Council, editors of the journal, and other authors. 


\title{
Worlding the Study of Normative Power: Assessing European and Chinese Definitions of the "Normal"
}

\author{
Emilian KAVALSKI \\ Li Dak Sum Chair Professor of China-Eurasia Relations and International Studies University of Nottingham Ningbo, China. \\ E-mail:emilian.kavalski@gmail.com

\section{Young Chul CHO} \\ Associate Professor, School of International Studies, Chonbuk National University, Jeonju, South Korea. \\ E-mail:yccho@jbnu.ac.kr (Corresponding Author)
}

This work was supported by the Ministry of Education of the Republic of Korea and the National Research Foundation of Korea (NRF-2016S1A3A2923970) and a Taiwan Fellowship by the Ministry of Foreign Affairs of the Republic of China on Taiwan.

\begin{abstract}
This study contributes to the nascent worlding of the study of normative power by undertaking a parallel assessment of Normative Power Europe (NPE) and Normative Power China (NPC). There seems to have been a qualitative change in the EU's and China's international standing. While in the immediate post-Cold War period the EU was asserting its ability to set the range of legitimate international behavior and China appeared to be a reactive adopter of such norms, in recent years China is positioned as a normative entrepreneur and the EU's ability has been challenged both in Europe and internationally. This study claims that such change in fortunes is not merely a result of recent developments, but pivots on the distinct repertoires of NPE and NPC - acquis communautaire for the EU and guanxi for China. The acquis communautaire suggests a "rulebased" framework for setting what passes for "normal" in global life, while guanxi offers a "relational" one. Such distinct points of departure have led to the evolution of distinct concepts and practices of normative power. The comparative study of NPE and NPC concludes by drawing attention to the nascent struggle for recognition of normative powers in global life.
\end{abstract}

Keywords: Acquis Communautaire, Normative Power China, Normative Power Europe, Guanxi.

\section{ÖZET}

Bu çalışma, Normatif Güç Avrupa (NGA) ve Normatif Güç Çin (NGÇ)’i değerlendirerek yeni oluşmakta olan normatif güç çalışmalarına katkı sağlamaktadır. $A B$ ve Çin’in uluslararası konumlarında niteliksel bir değişme olduğu gözlenmektedir. Soğuk Savaş sonrası dönemde, AB uluslararası alanda meşru olarak kabul edilen davranışların kapsamını belirleme kapasitesi olduğunu ileri sürerken, Çin bu tarz normları reaktif bir şekilde benimser görünmekteydi. Son yıllarda ise Çin normatif bir girişimci olarak kendini konumlandırırken, AB'nin yetkinliğine hem Avrupa'da hem de uluslararası alanda meydan okunmaktadır. Bu makale, yaşanan değişimin sadece son zamanlarda yaşanan gelişmelerin bir sonucu olmadığını, NGA ve NGÇ’nin eksenlerinin de belirleyici olduğunu savunmaktadır. Topluluk müktesebatı, küresel düzende "normal” olarak kabul edilenin "kural temelli" bir çerçeve içinde belirlenmesi gerektiğini savunurken, guanşi "bağlamsal” bir çerçeve önermektedir. Bu farklı ayrılma noktaları, normatif gücün farklı konsept ve pratiklerinin gelişimine neden olmaktadır. NGA ve NGE’nin karşılaştırıldığı bu çalışma, küresel düzende normatif güçlerin tanınması için ortaya çıkmakta olan mücadeleye dikkati çekerek sona ermektedir.

Anahtar Kelimeler: Topluluk Müktesebatı, Normatif Güç Çin, Normatif Çin Avrupa, Guanşi. 


\section{Introduction}

This article proposes a framework for the study of normative power beyond the Eurocentric frame through a parallel assessment of normative power Europe and normative power China. The parallel investigation of normative powers promises to uncover opportunities for a contextual exploration of the intellectual foundations not only of multi-polarity, but also to the proliferation of a cacophony of normative languages in global life. The point of departure for such an exploration is the recognition that in the study of global affairs, where multiple practices, worldviews, and traditions interact, the rigid singularity of its Anglophone Eurocentism has left no room for alternative discourses, norms, and outlooks; in fact, it beckons International Relations (IR) to learn "new ways of thinking and doing, being and relating". ${ }^{1}$ As such, while IR may claim to be global in its reach, it is less so in its cultural underpinnings. ${ }^{2}$ The mainstream has thus been found to be complicit in the production of an "illusion of reality in its most deceptive sense - namely, as the ability to make believe with the power and artifice to enchant and hypnotize." ${ }^{3}$ This article recognizes the emergence of alternative (and oftentimes) contending conceptualizations of political goods in global life and the appropriate way(s) for their attainment. Such contextualization acknowledges that normative powers are not in the business of enforcing orders over other actors, but of engaging other actors in shared practices.

The parallel assessment of normative power insists that for the EU, its normative power is pivoted on the legal framework of the acquis communautaire, while for China - it is the practices of guanxi. Acquis communautaire represents the accumulated legal obligations and institutional properties shared by the EU member states. Reflecting the complex history of European integration, the acquis communautaire is an evolving framework setting "the rules of the game" both within the Brussels-based bloc and for its interactions with the outside world. ${ }^{4}$ It is often formal and written. Guanxi (traditional: 關係 simplified: 关系) is one of the words making the Chinese term for the discipline of International Relations - guoji guanxi (traditional: 國際關係 simplified: 国际关 系). Yet, its content and practices are far more expansive than the ones envisioned by the English word "relations". Drawing on its Confucian origins, guanxi denotes an ongoing commitment to act in accordance with social demands and expectations established and maintained through intricate relational networks engendered by the practice of unlimited exchange of favours and underpinned by reciprocal obligations, assurances, and mutuality. ${ }^{5}$ It often informal, unwritten, and contextual. The critical normative inflection of guanxi is that the premium conferred to reciprocity accords social relations greater significance and relations are usually seen as ends in and of themselves rather than means for realizing various goals.

With regard to the comparative study of normative power Europe and normative power China, both acquis communautaire and guanxi bespeak distinct modes of international outreach - the former suggests a "rule-based" and the latter outlines a "relational" framework for the management of a dynamic and interactive environment. The argument is that such distinct points of departure have led to the evolution of distinct concepts and practices of normative power. ${ }^{6}$ The required qualification

1 Pinar Bilgin and L.H.M. Ling, Asia in International Relations, Abingdon, Routledge, 2017, p.7.

2 John M. Hobson, The Eurocentric Conception of World Politics, Cambridge, Cambridge University Press, 2012.

3 Necati Polat, International Relations, Meaning, and Mimesis, London, Routledge, 2012, p.7.

4 Emilian Kavalski, "From the Western Balkans to the Greater Balkans Area: The External Conditioning of 'Awkward' and 'Integrated' States”, Mediterranean Quarterly, Vol.17, No.3, 2006, p.86-100.

5 Emilian Kavalski, "Relationality and Its Chinese Characteristics”, The China Quarterly, Vol.226, 2016, p.551-559.

6 Emilian Kavalski, "Recognizing Normative State Action in International Life”, Political Studies Review, Vol.15, No.2, 2017, p.231-242. 
is that this parallel assessment focuses on the ideal types implicit in the normative powers of the EU and China. The following sections therefore do not intend an account of the bilateral interactions between two normative powers. Instead, by outlining the ideal types of normative power Europe and normative power China, this inquiry draws attention to the nascent struggle for recognition of normative powers in global life.

At the same time, this article brings in dialogue the form and substance of the languages and experiences of the diverse infinitely complex worlds cohabiting in global life. The concluding section evokes these registers of worlding mutuality by elaborating the ways in which a relational IR knowledge-production embraces the ethical and political promise of transcending the expected by engaging creatively with the contradictions, challenges, and opportunities of an entangled and unpredictable global life. Inhabiting a complex universe reveals not only the interdependence between international actors, but also their mutual implication in each other's interactions and roles as well as the overwhelming embeddedness of these relations in the world. The project of worlding IR uncovers a range of alternative stories that need to be heard. The "international" that it engenders is an inherently fragmented and dynamic process. Such relationality becomes coextensive of and standing together with the interpolating spontaneity of surrounding events and things. The contention is that such endeavours generate novel and meaningful opportunities for a thorough reconsideration of the explanation and understanding of the disciplinary mainstream. International Relations studies thus become more democratic and truly global.

\section{Worlding the Study of Normative Power}

Few would blame the international media for overlooking to report the Ukrainian Silk Road International Forum held in Kiev on the 8th November 2016. Yet, as commentators were struggling to come to terms with the shocking results from the presidential elections in the USA, the Kiev Forum seemed to presage a similarly momentous realignment in European affairs. Coming in the wake of the $5^{\text {th }}$ Meeting of the Heads of Government of Central and East European Countries and China (better known as the "16+1") held in Riga (Latvia) on 5 November 2016, the Ukrainian Silk Road Forum aimed to send a strong signal to Beijing that Ukraine is eager to be included in the " $16+1$ " mechanism. While the immediate objectives of the Ukrainian government were to secure much-needed economic investments associated with China's gargantuan "One Belt, One Road” (OBOR) connectivity project, Kiev's underlying motivation seems to be in line with its foreign policy rationale since the dissolution of the Soviet Union - namely, that it "belongs to Europe" rather than a geopolitical reconfiguration pivoted on Russia. What is different this time is that Ukraine's "European future" appears to be associated with a project promoted by Beijing rather than Brussels.

Ukraine is far from the only country in the region to indicate a possible shift in the normative compass of its foreign policy outlook. To varying degrees, all the Central and East European (CEE) countries participating in the "16+1" meeting have shown that apart from the "hardware" of investment opportunities provided by the OBOR initiative, their engagement with Beijing is also driven by the "software" of ideas and values that backstops China's connectivity projects. This appears to be a qualitatively new context for Sino-EU relations. Whilst such policy diversification has become

7 Xinhua, "Spotlight: Ukraine seeks to join " $16+1$ " mechanism for participation in China's Silk Toad Initiative", 8 November 2016, http://www.xinhuanet.com/english/2016-11/08/c_135812518.htm (Accessed on 20 February 2018). 
commonplace across much of the so-called developing world, its emergence in the CEE region seems to challenge the very identity of the $\mathrm{EU}$ as a normative power. It was the very willingness of the postcommunist countries to internalize the projected "European model" that has convinced the EU of its ability to set the domain and range of legitimate international behaviour. In this way, the CEE states provided the enabling environment for normative power Europe by demonstrating the value rationality of making policy choices based on EU norms. As many have stated, the EU's influence has always been subject to contestation beyond the realm of its accession programs, however its normative appeal has never appeared in doubt within the domain circumscribed by EU-membership and prospect of membership. For this reason, many commentators have been insisting that the EU is a continental rather than a global international actor. Yet, in the wake of the Eurozone debt crisis and the Brexit referendum in the UK, there seems to be a reversal in roles - not only is the EU no longer the dominant partner in the Sino-European relationship, the coherence of its international identity appears to be challenged by the growing dependence of EU member states on Chinese trade. ${ }^{8}$

Thus, while in the immediate post-Cold War period China appeared to be a reactive adopter of international norms, Beijing has been quite willing to adopt activist stance since the appointment of $\mathrm{Xi}$ Jinping to the presidency. In other words, from a mere game-player, China has increasingly been finding itself in the role of a "game-maker" - not least, owing to (perceived and actual) American withdrawal from multilateralism in the wake of the election of Donald Trump to the US presidency. ${ }^{9}$ In particular, initiatives such as the OBOR connectivity project and the " $16+1$ " mechanism demonstrate China's potential to use its economic prowess to contest dominant norms, rules, and arrangements. In this respect, as China becomes increasingly involved in Europe and the European neighbourhood, the respective normativity of the EU's and China's international outreach will not only interact more often, but also demands ongoing reconsideration. In particular, China's economic entrepreneurship in Europe need not be a source of anxiety that petrifies any form of critical thought, but it "should trigger significant reflection about the decline of the EU's ability to act as a political-economic centre of gravity, even for countries in its immediate periphery". ${ }^{10}$

The discipline of International Relations (IR) has struggled to foster different ways of seeing and encountering the world that can help it generate meaningful answers to the pressing questions of our times. The dominant models of IR are complicit in the construction of a world that is unravelling socially, fracturing economically, and deteriorating ecologically. ${ }^{11}$ There is an urgent need for a change in perception, outlook, and vision that can break free from the Eurocentrism and the deterministic logic of control that informs the IR mainstream. ${ }^{12}$ Responding to this call, the present study asserts that non-Western normative orders are just as legitimate as Western ones. Yet, the IR mainstream has remained peculiarly and poignantly resistant to the insertion of post-Western imaginary on the agenda of the "international". Therefore (and, perhaps, unsurprisingly), despite the intellectual challenges

8 Hans Kundnani, “How Economic Dependence Could Undermine Europe's Foreign Policy Coherence”, 21 January 2016, http://www.gmfus.org/publications/how-economic-dependence-could-undermine-europes-foreign-policycoherence (Accessed on 20 February 2018).

9 Niv Horesh and Emilian Kavalski, Asian Thought on China's Changing International Relations, Basingstoke, Palgrave, 2014.

10 Agatha Kratz and Dragan Pavlićević, "Belgrade-Budapest via Beijing: A Case Study of Chinese Investment in Europe”, 21 November 2016, http://www.ecfr.eu/article/commentary_belgrade_budapest_via_beijing_a_case_study_of_ chinese_7188\# (Accessed on 20 February 2018).

11 Steve Smith, "Singing Our World into Existence”, International Studies Quarterly, Vol.48, No.3, 2004, p.499-515.

12 Navnita Chadha Behera, "Re-Imagining IR in India”, Amitav Acharya and Barry Buzan (eds.), Non-Western International Relations Theory, Abingdon, Routledge, 2010, p.92-116. 
posed by the growing interdependence of global life, the bulk of IR inquiry is still dominated by preoccupations with the West/Global North. ${ }^{13}$

In this setting, it is difficult to ignore that IR theory suffers from a Columbus syndrome. ${ }^{14}$ The 1492 voyage of Christopher Columbus set in motion the period of European conquest - often referred in Western scholarship as the "age of discovery" and by indigenous communities around the world as a period of "invasion and dispossession". However, Columbus himself failed to recognize the newness of the "New World" that he supposedly discovered. It is well-known that he did not think that he had reached a new continent, but that he had arrived at the eastern shores of Asia. More importantly, in the context of the current discussion, his encounter with the various Amerindian peoples was effectively prevented by his own cultural, religious, and ideological prejudices. It might appear puzzling today, but Columbus refused to recognize that the Amerindians spoke a different language from him. Instead, he merely assumed that the indigenous populations were unable to speak. Thus, "Columbus's failure to recognize the diversity of languages permits him, when he confronts a foreign tongue, only two possible, and complementary, forms of behaviour: to acknowledge it as a language but to refuse to believe it is different; or to acknowledge its difference but to refuse to admit it is a language". ${ }^{15}$ In this respect, Columbus always already "knows in advance what he will find" ${ }^{16}$ and acknowledges only the things that fit his preconceived model, while ignoring all the aspects that were incongruent.

The claim here is that the IR mainstream suffers from a similar condition to that of Columbus (which goes beyond the mere cognitive dissonance of the discipline). Thus, when it encounters "other" concepts, practices, and experience of the "international", IR more often than not reverts to the prism of its Columbus syndrome: either it recognizes them as narratives about world politics but does not acknowledge that they are different; or acknowledges that they are different, but refuses to admit that they are part of IR (thereby relegating them to fields such as cultural studies, area studies, anthropology, etc.). In either case, the IR mainstream tends to prioritize ontologies of separation rather than connectedness -and this is the real source of its Columbus syndrome. As a result, IR prescribes "imperialistic epistemologies which assume that the world is one and that it is knowable on a global scale within single modes of thought, and thus manageable and governable in those terms". ${ }^{17}$ Thus, all that falls outside the "authorized imaginaries" of IR is scorned as primitive, magical, and animistic, and, thereby, delegitimized and neglected. ${ }^{18}$ Consequently, in the view of Western modernity and rationality, reality and its phenomena are assumed to be abstract and generalizable wholes, which are singular, out there, and defined; consequently, "the anxiety against relativism is one of the most prevailing forces for gatekeeping in IR. It becomes the cause of a constant blackmail: in dichotomous thinking, we only get to choose between one pole or the other, never both, never something else" ${ }^{19}$

In order to rectify this trend, this study offers a worlding of the concept of "normative power" by setting up an encounter with its "Chinese characteristics". Despite its centrality to European IR,

13 Arlene Tickner and David Blaney, Thinking International Relations Differently, London, Routledge, 2012; Emilian Kavalski, "The Guanxi of Relational International Affairs", Chinese Political Science Review, Forthcoming.

14 Kavalski, The Guanxi of Relational International Theory, London, Routledge, 2018, p.1-15.

15 Tzvetan Todorov, The Conquest of America and the Question of the Other, New York, Harper \& Row, 1982, p.30.

16 Ibid., p.17.

17 Janet Conway and Jakeet Singh, "Radical Democracy in Global Perspectives”, Third World Quarterly, Vol.32, No.3, 2011, p.701.

18 Amaya Querejazu, “Encountering the Pluriverse”, Revista Brasiliera de Politica Internacional, Vol.59, No.2, 2016 , p.8.

19 Ibid., p.7; Emilian Kavalski and Magdalena Zolkos, “The Recognition of Nature in International Relations”, Patrick Hayden and Kate Schick (eds.), Recognition and Global Politics, Manchester, Manchester University Press, 2016, p.147. 
the notion of normative power has had surprisingly little traction in the analysis of the nascent agency of other international actors - especially, the growing prominence of Asian actors such as China. Instead, the concept of soft power remains the dominant framework for those seeking explanation of Beijing's increasing influence. There are several reasons for this development. On the one hand, owing to the perceived complexity of the European Union (EU), Asian scholars have been disinterested to engage with the propositions and concepts of European IR. On the other hand, European IR scholars have expanded little effort to translate the applicability of their terminology to non-EU actors and contexts (both because of the all-pervasive nature of the EU and also because of the positioning of Asian Studies outside of the IR curriculum). At the same time, both European and Asian IR scholars have tended to frame their analysis in reaction to the dominant American IR view, which-instead of aiding - appears to have further hampered engaging with each other. The following discussion intends to bridge these differences and contribute to a more relational knowledge-production in IR.

To begin with, Ian Manners launched the study of normative power with his pioneering analysis of the external relations of the EU. ${ }^{20}$ As he put it, it is the very ability to "shape what can be 'normal' in international life" that distinguishes the EU's model. Since Manners' intervention, it has become nearly impossible to discuss any aspect of the EU's foreign policy without at least a token reference to its "normative power". The literature on the topic has spawned perceptive and prolific conversations on the EU's identity and roles in global life as well as the import, impact, and trajectories of its foreign and security policies. In recent years, however, there has been a nascent attempt to world the study of normative. The project of worlding both invites and legitimizes non-Western contributions to the study and practice of both European Studies and International Relations (IR). On the one hand, such worlding intends to pluralize disciplinary inquiry by engaging previously excluded alternatives for thinking and doing world politics that have been forged both historically and in contemporary times by scholars, practitioners, and activists. On the other hand, such worlding offers productive openings for bringing into a meaningful conversation a wide range of cosmologies, power relations, and vulnerabilities than are typically accounted for by the narratives of IR. ${ }^{21}$

The worlding of normative power has offered strategies for going beyond its Eurocentric frame both by decolonizing its analytical framework and by widening the set of actors whose international agency it can meaningfully explain and understand. ${ }^{22}$ Owing to the so-called "shift to the East" in IR as a result of the growing prominence of Asian international actors, a considerable part of such worlding of normative power has been associated with the roles and agency of China. ${ }^{23}$ The proposition of such a normative dimension of Chinese foreign policy should not be surprising. It could be argued that the suggestion of a normative power China acknowledges an underlying feature of Beijing's international outreach at least since the 1950s - namely, the promotion of an alternative global order routing around superpower competition. The following sections offer a parallel assessment of the central features of the normative powers of the EU and China.

20 Ian Manners, “Normative Power Europe: A Contradiction in Terms?”, Journal of Common Market Studies, Vol.40, No.2, 2002, p.235-258.

21 Kavalski, The Guanxi of Relational International Theory; L.H.M. Ling, The Dao of World Politics, London, Routledge, 2015.

22 Zaki Laïdi, Norms over Force, Basingstoke, Palgrave, 2008; Nora Fisher Onur and Kalypso Nicolaïdis, “The Decentring Agenda", Cooperation and Conflict, Vol.48, No.2, 2013, p.283-303; Emilian Kavalski, "The Shadows of Normative Power in Asia: Framing the International Agency of China, India, and Japan”, Pacific Focus, Vol.29, No.3, 2014, p.303-328.

23 Emilian Kavalski, "The Struggle for Recognition of Normative Powers: Normative Power Europe and Normative Power China in Context", Cooperation and Conflict, Vol.48, No.2, 2013, p.247-267; Brantley Womack, "China as a Normative Foreign Policy Actor”, Nathalie Tocci (ed.), Who Is a Normative Foreign Policy Actor?, Brussels, CEPS, 2008, p.265-300. 


\section{Encountering the Spectres of the Past}

The phenomenon of normative power reveals an intriguing intersection of the discursive memory of the past with the context of the present and the anticipated tasks of the future. Both the EU and China are no strangers to this trend - in particular, their normative power reveals a reflexive construction of the past as the other which then frames their current and prospective international agency. ${ }^{24}$ In the case of Brussels, normative power reflects the securitization of division and war. It is the memory and devastation wrought on the continent by two world wars that backstops the EU's insistence on the binding rules of acquis communautaire that ensure legal proscription of the violent resolution of conflict. "Europeanization" gains urgency and immediacy because its alternative - disintegration seems certain to unleash processes that can undo the EU project. ${ }^{25}$ In the case of Beijing, it is the experience of national humiliation as a result of colonial incursions during the nineteenth century that underwrites the guanxi of China's relational normative outreach. Chinese foreign policy can thus be read as an attempt to dispel such memories by projecting not only confidence, but also a normative outlook proclaiming that others need not suffer humiliation either. ${ }^{26}$

Thus, it is not coincidental that the EU and China offer competing instances of normative power. China's rising prominence in international life is motivated by the memory of "losing face", which remains at odds (if not antithetical) to the EU's liberal expansionism. The legacy of colonialism is oftentimes occluded from the conversations on normative power Europe. Such tendency is illustrative of a systemic "politics of deflection" in mainstream IR, which diverts attention from the violence -both epistemic and otherwise- that its Eurocentrism perpetuates. ${ }^{27}$ In this respect, the presumed universalism of the EU's rules, norms, and values (especially, the conviction that the application of the acquis communautaire is ahistorical and resides exclusively in the norm itself) overlooks the legacy of the forcible inclusion of the rest of the globe into the Westphalian international system. Such "civilizational conceits" seem to suggest that normative power Europe is still obligated to the export of EU values "in the name of some outmoded messianic mission". ${ }^{28}$ In contrast, China seems to posit a normativity steeped in the "singularly historical practice of universal principles that is open to emulation not as a universal pattern, but for its procedures in articulating the universal to concrete historical circumstances". ${ }^{29}$

Such contextualization reframes normative power as a "relational practice" simultaneously attuned and open to the contradictions, challenges, and opportunities of a dynamic and unpredictable global life. ${ }^{30}$ Moreover, in such a dialogical context the possibility for constructing "new histories" emerges by altering the suspicion and bias from past interactions and opening up opportunities for new relationships founded on the affective feeling (ganqing) produced by the process of repeated

24 Emilian Kavalski, Central Asia and the Rise of Normative Powers: Contextualizing the Security Governance of the EU, China, and India, New York, Continuum, 2012.

25 Emilian Kavalski, “Towards a Relational Knowledge-production in International Relations”, Korean Political Science Review, Vol.51, No.6, 2017, p.147-170.

26 Kavalski, “The Struggle for Recognition of Normative Powers”, p. 257.

27 Jeanne Morefield, Empires without Imperialism, Oxford, Oxford University Press, 2014; Davis Walton and Emilian Kavalski, Power Transition in Asia, London, Routledge, 2017.

28 Laïdi, Norms over Force, p.51; Onur and Nicolaïdis, "The Decentring Agenda”; Emilian Kavalski, "Chinese Concepts and Relational International Politics”, All Azimuth, Vol.7, No.1, 2018, p.87-102.

29 Arif Dirlik, “The Idea of a 'Chinese Model”, China Information, Vol.26, No.3, 2012, p.291.

30 Yaqing Qin, "Relationality and Processual Construction", Social Sciences in China, Vol.30, No.3, 2009, p.9; Emilian Kavalski, World Politics at the Edge of Chaos: Reflections on Complexity and Global Life, Albany, NY, State University of New York Press, 2015. 
interactions. ${ }^{31}$ The point here is that guanxi ties are volitional - actors intentionally commit to the interaction by demonstrating their willingness to exercise self-restraint. In such a relational setting, agency (especially, international agency) is not about the intentional projection of self-interest, but about strategic receptivity - i.e., "knowing oneself insofar as one is related to others, and knowing others insofar as others are related to oneself" ${ }^{32}$

Guanxi, thereby, presages an understanding of international action and agency - both cognitively and affectively - as simultaneously shaped and mediated by ethical obligations and commitments to others (the structure and content of which is acquired through the very relationships by which ethical obligations and commitments to others are disclosed). Rather than impeding the policy process, such contextual attunement discloses the unexpected opportunities made possible by the pattern of $g u a n x i$ - for instance, the unintended evolution of the Shanghai-5 into the "One Belt One Road" initiative via the Shanghai Cooperation Organization. ${ }^{33}$ As the hub of social knowledge and social life, the patterns of guanxi intimate that shared understandings are not imposed as rules, rights, or obligations, but emerge in and from the very process of interaction. In other words, the relational normativity of China's global outreach is embedded in the very practices through which ideas of sociality are shared.

\section{Rules or Relations for Global Affairs}

The claim here is that the distinct repertoires of normative power promoted by the EU and China reflect different logics of action. As suggested, normative power Europe appears embedded in a rule-based governance mechanism of acquis communautaire that expects others to follow the lead of Brussels, while normative power China exposes a mode of relational governance inviting long-term interactions with Beijing. Many have remarked that the Sino-EU relationship is oftentimes marked by misunderstandings; yet, few have located their origins within the distinct logics of action of their normative outlook. In this respect, while the EU's interactions are rooted in contractual obligations, internalization of promoted norms, and compliance, China's foreign relations prioritize sociality, personalization, and reciprocity. ${ }^{34}$

The framing of the EU as a normative power pivots on the externalization of its politicoeconomic framework steeped in the traditions of liberal democracy and backstopped by the mechanisms of the open market. Labelled as the "Europeanization" of world affairs, the EU's normative power has become coterminous with the transformative potential of its accession-driven conditionality of candidate (and prospective candidate) countries. ${ }^{35}$ The kind of normalization of international relations suggested by normative power Europe reflects such expectations to comply with the rules embedded in the "European model". According to Manners, these rules reflect both the "core" norms of the EU (peace, liberty, democracy, rule of law, and respect for human rights and fundamental freedoms) and its "minor" norms (social solidarity, antidiscrimination, sustainable development, and good governance). ${ }^{36}$ Both the core and minor norms of the EU are codified in the

31 Yaqing Qin, “Rule, Rules, and Relations”, Chinese Journal of International Politics, Vol.3, No.2, 2011, p.129-153.

32 Lucian Pye, "Factions and the Politics of Guanxi", The China Journal, Vol.34, No.2, 1995, p.42.

33 Emilian Kavalski, "Shanghaied into Cooperation: Framing China's Socialization of Central Asia" Journal of Asian and African Studies, Vol.45, No.2, 2010, p.131-145.

34 Knud Erik Jørgensen and Rueben Wong, “Social Constructivist Perspectives on China”, Jianwei Wang and Weiqing Song (eds.), China, the European Union, and the International Politics of Global Governance, Basingstoke, Palgrave, 2016, p.61.

35 Kavalski, "From the Western Balkans to the Greater Balkans Area", p.86-100.

36 Manners, "Normative Power Europe”, p.15. 
acquis communautaire. As the socialization experienced by the CEE states amply illustrates, it was the very willingness of these countries to adopt the rules and values promoted by Brussels that provided the enabling environment for the EU's normative power. As a result of this post-Cold War experience, the EU's normative power has become inured to demand compliance with acquis communautaire through the "carrots" of its membership project and the "sticks" associated with the threat of exclusion from its benefits. Yet, as many have pointed out, such relentless demand for compliance with specific standards of behaviour has significantly undercut the EU's socializing effects outside of the framework of the accession process. ${ }^{37}$

It is in this setting that China has begun to be seen as a distinct normative power. It has to be acknowledged that the suggestion of normative power China reflects not so much what China actually does, but an expanding perception of what it does and how it does it. China is increasingly positioned as "a metaphor for 'difference" to the seeming Western hegemony over the post-World War II world order. ${ }^{38}$ The key feature of China's normativity appears to be its relationality. Rather than a linear cause-and-effect mechanism, the dynamics of normative power China are governed by its own social logic. ${ }^{39}$ Thus, in contrast to the binding commitments enshrined in the EU's rule-based compliance, the relationality of China's normative power revolves around the shared expectations of reciprocity implicit in the framework of guanxi. Consequently, while rules, norms, and values are the embodiment of normative power Europe, such rules, norms, and values are merely contingent figurations - not the embodiment - of normative power China. ${ }^{40}$ The patterns of interactions outlined by such circumstantial normativity are not premised on a "socialization game" in the traditional sense of the term (i.e., they are neither about identity change, nor about the internalization of externallypromoted norms), but reveal a mutual commitment and interest in maintaining the interaction for the long term. ${ }^{41}$ What is normatively important emerges not as a result of individual decisions (i.e., outside of and prior to processes of interaction), but in the context of doing things together. Shared understandings are not imposed as rules, rights, and duties, but emerge in, from, and through the very process of interaction and are contingent on the (contextual) interpretation and relational signification of the memory of previous social experiences. Such circumstantial normativity requires skills for living (if not thinking) in a social environment beyond the control of any of the participating actors.

Thus, in the ideal type, relationality is about what happens between two or more actors in the particular spatial and temporal context of their interactions. Such contingency does not prevaricate against impact on the pattern of relations in the broader international society; however, this is not the main reason for engaging in interaction. Instead, the aim is to keep the relationship going by "harmonizing" (not "socializing") concrete relationships. This does not mean that such interactions are bereft of power and influence, but that the patterns of relational power intertwining the participating actors are not aimed at changing others (which is the central theme of normative power Europe). Instead, relationality is focused on the management of hostile role-playing in order to maintain the longevity of interactions (through ongoing reciprocity). Thus, the procedural norms that emerge in the context of doing things together impact on the modes of interaction (and vice versa).

37 Kavalski, Central Asia and the Rise of Normative Powers.

38 Shaun Breslin, “The China Model”, International Affairs, Vol.87, No.6, 2011, p.1324.

39 Jørgensen and Wong, China, the European Union, p.56.

40 Jeremy Paltiel, The Empire's New Clothes, New York, Palgrave Macmillan, 2007, p.236.

41 Kavalski, "Relationality and its Chinese Characteristics", p.551-559. 


\section{Multilateralism and Multipolarity in World Affairs}

The normative power of both the EU and China belies shared desire for foreign policy independence on the world stage. In fact, the demand for a more plural world has been a crucial feature of the SinoEuropean relationship. ${ }^{42}$ However, drawing on their divergent historical experiences (as well as the distinct normative outlooks that these have informed), the EU and China aspire to different ideals for a desired world order. Instrumentally, many have pointed that this normative divergence pivots on the concepts of multilateralism and multipolarity. The former is usually associated with the international outreach of the EU, while the latter is championed by China. ${ }^{43}$

For Brussels, the content and practices of multilateralism open multiple avenues for the construction of a rule-based international system consistent with its normative power. For Beijing, multipolarity provides opportunities for promoting its global outreach without interference in the domestic affairs of states. Thus, while the EU's version of multilateralism furnishes the aim of constructing a neoliberal political and economic order governed by Western principles and practices, China's version of multipolarity insists on the coexistence of multiple poles of power in the world whose legitimacy should not be contested. Drawing on the ideals of a democratic peace, normative power Europe advocates a uniform world order in which all participants should follow formal (and externally-imposed) rules. Drawing on the ideals of harmonious society, normative power China propounds a network view of the global system in which multiple orders overlap, coexist, and constantly interact with one another and in which each participant is a hub of a complex and layered patterns of interactions. ${ }^{44}$

These distinct normative outlooks tend to be reflected in the EU's value-laden promotion of "post-modern statehood" and China's insistence on the inviolability of "state sovereignty". ${ }^{45}$ Reflecting its unique system of pulled sovereignty, the normativity of the acquis communautaire prescribes an order-building strategy through the externalization of EU-norms and their uniform insertion into the legal structure of its partners. In this setting, the understanding of state sovereignty has gradually become conditional on the capacity of governments to deliver individual human rights. Associated with a global post-Cold War push towards democracy, normative power Europe has sought to promote the pulling of decision-making powers towards (Western-dominated) international institutions. ${ }^{46}$

In contrast, China's insistence on sovereignty reflects a normative strategy for nurturing mutual expectations premised on respect for each other's integrity. ${ }^{47}$ China's respect for its interlocutors has contributed to (what Philip Nel labels as) the struggle of awkward states-regardless of where in the world they are located - "against their own invisibility in terms of the reigning [Western] discourses of development, modernization, and global economic and cultural integration". Thus, the practices of guanxi reveal the profound ontological implications of interactions - "the appreciation of what is important to you in terms of your own self-conception, in contrast to the general expectations that

42 Shouyuan Shen, "Sino-European Relations in the Global Context", Asian Survey, Vol.26, No.11, 1986, p.1164-1183; Chengxin Pan and Emilian Kavalski, "Why Theorize China's Rise”, International Relations of the Asia-Pacific, Forthcoming.

43 David Scott, "Multipolarity, Multilateralism, and Beyond”, International Relations, Vol.27, No.1, 2013, p.30-51.

44 Emilian Kavalski, “Timescapes of Security: Clocks, Clouds, and the Complexity of Security Governance”, World Futures, Vol.65, No.7, 2009, p.527-551; Ling, The Dao of World Politics.

45 Kavalski, Central Asia and the Rise of Normative Powers.

46 Bronween Jones, "Global Governance”, Cambridge Review of International Affairs, Vol.26, No.1, 2013, p.49-70.

47 Kavalski, “The Struggle for Recognition of Normative Powers”, p.247-267. 
[the international] society may impose on you [provides] an increasing scope for self-realization" ${ }^{48}$ The inference here is that international agency emerges in a community not in a vacuum. In particular, it is the commitment to deliberate and unconditional sociality that motivates shared meaninggeneration. The driving force appears to be the practice of doing things together which affords ongoing opportunities for interpretative articulation and re-articulation of international exchanges that can engender, enhance, and reaffirm the reputational profile of participating actors.

Such normativity can explain China's general aversion to the imposition of conditionality on its partners. What passes for world affairs in such a context is not about "the application of abstract norms to cases," but about "a set of particular international relationships, with concrete obligations defined within the context of each relationship" ${ }^{49}$ In fact, it is through the practice of doing things together that the normative and the ideational structure of global life gets engendered.$^{50}$ In this respect, the interactive dynamics of communities of practice stimulate new and contextual definitions of the "common good" by drawing attention to the distinct roles and positions that international actors take in diverse spatial and temporal contexts. The crucial point here is that what changes in the processes of guanxi are the roles that actors play, not their identity, subjectivity, and/or individuality (as implied by the compliance mechanisms of acquis communautaire). This should not be misunderstood as a suggestion that identities (in contrast to roles) remain immutable. On the contrary, the point merely is that by focusing on identity change, mainstream analyses of EU's socializing capacity tend to reify misleading representational modes for explanation and understanding that freeze the flow of international interactions into static relationships that actors have, "as if they were those self-same, permanent objects whose interactions with the world produce external circumstantial changes to the objects". ${ }^{51}$

In the context of ongoing dynamic change implied by guanxi, actors are their relationships. Roles therefore are not about identities (or prescribed by them), but about acting on the world stage - an actor can play any role depending on the circumstances. Thus, rather than endogenous, roles are exogenous to actors and emerge in relation to the context of interaction and change over time and space. Consequently, role-demands do not emerge in the abstract, but are borne out of the process of interactions. Since roles are circumstantial, the qualitative innovation emerging from the dynamics of guanxi is that an actor can play any role on the world stage regardless of their identity. In this process, the patterns of guanxi reveal a new way of being present in the world through the binding power of deliberate interactions, which also involves an acknowledgement of the shared responsibilities between the participating actors.

\section{Normative Power beyond the Eurocentric Frame}

By outlining the normative power of the EU and China, the preceding section has indicated the nascent rise of normative powers - international actors demanding recognition for their ability to define the ramifications of the "normal" in global life. It would therefore be apposite to outline the elements of normative power, per se, rather than "normative power Europe" or "normative power China". As Ian Manners has noted, in its "purest form", the concept of normative power is ideational-i.e., it relies on

48 Philip Nel, "Redistribution and Recognition" Review of International Studies, Vol.36, No.4, 2010, p.970-971; Pan and Kavalski, "Why Theorize China's Rise".

49 Womack, "China as a Normative Foreign Policy Actor", p.265.

50 Kavalski, "The Struggle for Recognition of Normative Powers”, p.247-267.

51 Heesoon Bai and Hartley Banack, “To See a World”, Complicity, Vol. 3, No 1, 2006, p.10. 
"normative justification rather than the use of material incentives or physical force". ${ }^{52}$ Such framing involves a three-part understanding of normative power linking together its principles, actions, and impact. Firstly, the principles underpinning normative power should be seen as legitimate. Secondly, the actions undertaken by normative powers should be perceived as persuasive. Thirdly, if normative power is to be attractive, its impact must emerge from socialization. Thus, Manners' claim is that the "consequences" of the concept of normative power is to envision the possibility of "more holistic, justifiable, and sustainable world politics". ${ }^{3}$ The contention here is that while relevant, Manners' "purest form" of normative power is profoundly embedded in the cognitive framework of EU-centric explanation and understanding.

In this respect, the question here is to what extent "normative power Europe" can be used as the template for a general model (if not theory) of normative power in world politics. Chinese commentators have insisted that the dynamics of inclusion and exclusion underpinning the EU model lack an "ideal for the world", because of its self-aggrandizing rule-based governance pattern which "enhances the integration of a region [i.e. Europe], but deepens its separation from the world".54 Others have posited that by "detaching normative discourse from concrete realities" the assumed universalism of the atomistic ontology of normative power Europe renders "normative discourse monological and potentially violent by ignoring or excluding ethico-political concerns of different others" ${ }^{\text {.5 }}$ This section therefore challenges some of the universalizing claims implicit in the normative power Europe model by outlining the key features of normative power emerging from the discussion of normative power China. The three-step that emerges links together interaction, deliberate relations, and communities of practice.

\section{Interaction}

The claim here is that the ability of a normative power to exert influence is contingent on its capacity to generate locally appropriate interactions. This study (borrowing from Robert Jervis ${ }^{56}$ ) indicates several reasons why this is significant. Firstly, results cannot be predicted from looking only at separate actions - in particular, the tendency to engage only with the agency of normative powers. Instead, outcomes emerge in the context of interactions-especially, interactions that are dialogical rather than objectifying. Secondly, "strategies depend on the strategies of others". Thus, dialogical relationships indicate that "the success and failures of policy are determined interactively." Significantly, the process of interaction empowers local participants and enhances the perception that they (and their inputs) are respected. Thirdly, "behaviour changes the environment"- that is, the exercise of normative power has its own evolutionary effects. ${ }^{57}$ Thus, it is through dialogical relationships that normative powers can have impact on the behavior of target states. To put it bluntly, it is by engaging in interactions that definitions of the "normal" gain their causal effects. Thus, normative power is not merely about the initiation of "rule-based governance" (as the case of the EU seems to indicate), but mainly about "relational governance". 58 The focus on interactions suggests that definitions of the "normal"

52 Manners, “The Concept of Normative Power in World Politics".

53 Ibid.

54 Tingyang Zhao, "Rethinking Empire from the Chinese Concept "all-under-heaven”, Social Identities, Vol.12, No.1, 2006, p.38.

55 Heikki Patomäki, After International Relations, London, Routledge, 2002, p.158.

56 Robert Jervis, System Effects, Princeton NJ, Princeton University Press, p.23-25.

57 Ibid. p.23-25; Kavalski and Zolkos, “The Recognition of Nature in”, p.148.

58 Yaqing Qin, “Rule, Rules, and Relations”, p.129-153. 
are negotiated in the relations among participating actors. In other words, interactions suggest that normative powers should have the capacity to live with and in ambiguity.

\section{Deliberate Relations}

It needs to be stressed here that normative power rests not just on any kind of interaction, but the deliberate practice of interaction - the purposeful and repeated effort to improve interactions and open oneself to the unpredictability of engaging with others. Translated into the language of world affairs the notion of deliberate practice suggests that normative powers deliberately seek to construct learning situations that foster "generative relationships". Owing to the dynamic nature of such interactions, what passes for world order is not only constantly changing, but demands ongoing commitment to participating in and maintaining relations. Such framing challenges the atomistic metanarrative of IR by proposing a relational ontology in which global life resonates with and through complex and interpenetrating presences whose sociability is infused with the contingent opportunities inherent in the encounter with the other. Thus, what is normatively important emerges not as a result of individual decisions, but in the process of deliberate relations with others. In other words, definitions of the "normal" become meaningful in the context of doing things together with them. Such commitments should not be misunderstood as a call for new hegemonic hierarchies privileging one lived reality over another. The relational ontologies of normative power beyond the Eurocentric frame do not proscribe antagonism, nor do they suggest that its elimination is required. ${ }^{59}$ Difference - including radical difference - is not merely desirable, it is the very condition of possibility for the self-organizing emergence of global life. In other words, difference belies 'interdependence-in-antagonism' - a normative stance that treats cooperation and competition as corresponding forces which underpin the mutual dependence of all those inhabiting global life. ${ }^{60}$ In other words, the relationality of such deliberate relations recall an outlook which favors contextual sensitivity to the subtleties of specific interactions at the expense of strict adherence to precise and rigid formulations.

\section{Community of Practice}

The inference here is that normative agency emerges in a community not in a vacuum. As suggested, it is the relational (rather than the rule-based) nature of normative power that makes its recognition a group process. Thus, the focus on communities of practice suggests that the definitions of the 'normal' are an acquired characteristic of an imagined community of interactions constituted by repeated deliberate practice. In other words, the "normal" is an outcome of dialogical "normbuilding" in a community of practice. The point here is that rather than "we-feeling", communities of practice foster "we-doing". ${ }^{61}$ The lack of conditionality of "we-doing" enables normative powers to engage "relations and elements of irreducible multiplicity, incongruence, and contingency". ${ }^{62}$ Thus, regardless of however loose or amorphous they are, communities of practice fashion negotiated outcomes in the process of doing things together. This understanding backstops an ethic of "living otherwise-relationally" 33 -namely, the cultivation of relational practices and nuanced

59 Querejazu, "Encountering the Pluriverse”, p.11.

60 Patomäki, After International Relations, p.62.

61 Kavalski, , “Towards a Relational Knowledge-production”, p.163.

62 Simon J. Smith and Emilian Kavalski, “NATO’s Partnership with Central Asia”, Emilian Kavalski (ed.), The New Central Asia, Singapore, World Scientific, 2010, p.31.

63 Cristina Rojas, “Contesting the Colonial Logics of the International”, International Political Sociology, Vol.10, No.4, 2016, p. 370 . 
adaptations sensitive to the emergent, historically-contingent, and self-organizing character of the "international". The study of normative power beyond the Eurocentric frame views global life as a messy social reality, always emergent, embedded in contingent spatio-temporal contexts, and shaped by interrelations with others (as well as the multitude of meanings that such interactions engender as their iterations are themselves inseparable from the multiple webs of relations through which such communication gets refracted).

\section{Conclusion: The Struggle for Recognition of Normative Powers}

This study has undertaken a parallel assessment of the ideal type of normative power implicit in the international outreach of the EU and China. As explained, the EU has developed a rule-based model pivoted on its acquis communautaire, while China develops a relationship-based one informed by the patterns of guanxi. Even though they are "self-made international actors", the suggestion is that normative power is not entirely an intrinsic property of an actor, but depends on the kind of interactions it engenders in specific contexts and the way such interactions frame the responses of its interlocutors. ${ }^{64}$ The parallel assessment of the ideal types of normative power Europe and China suggest a desire to be recognized as actors that are not only capable, but who also have the right to set the ramifications of the "normal" in global life. Thus, the definition of what passes for "normal" in global life entails a deliberate practice of interaction, informed by an actor's willingness to suspend evaluations of others as long as they engage in shared practices. It has to be acknowledged that such relational framing of normative powers promises to heal the habits of control, manipulation, and exploitation associated with IR's Columbus syndrome and its insistence on the separation between subject and object, knower and known, self and other, mind and matter.

The contention is that the relational knowledge-production emerging from the study of normative power beyond the Eurocentric frame generates novel opportunities for a thorough reconsideration of the explanation and understanding of the disciplinary mainstream. Such an endeavor is not intended to brandish relationality - both in the worlding of normative power and in the decentering of IR - as either a panacea for the crises plaguing the global condition or the flaws of the disciplinary purview. Instead, relationality offers a range of alternative stories that need to be heard. It is integral to the project of producing "worlds and knowledge otherwise" by actively seeking to change "the terms and not just the content of the conversations". ${ }^{65}$ Such decentering of the notion and practices of normative power resonates with the emancipatory mutuality of many different ways of knowing and being in global life. In this setting, the relationality lens helps outline the contested terrain of post-Western IR as a space for dialogical learning, which encourages engagement with the possibilities afforded by the interactions of multiple worlds and privileges the experiences and narratives of neither of them. At the same time, the disruption of the entrenched atomistic ontology of IR can contribute meaningfully to projects for equitable, just, and sustainable living. In this respect, the study of normative power beyond the Eurocentric frame should be read neither as a mode, nor a figuration of a relativism premised on disinterest and detachment, but as an ethical (and not only) stance of emancipatory relationality. ${ }^{66}$

64 Kavalski, “The Struggle for Recognition of Normative Powers”, p.249.

65 Arturo Escobar, "Worlds and Knowledges Otherwise”, Cultural Studies, Vol.21, No.2/3, 2007, p.181; Emilian Kavalski and Magdalena Zolkos, Defunct Federalisms: Critical Perspectives on Federal Failure, London, Routledge, 2008, p.12.

66 Erika Cudworth et al., Posthuman Dialogues in International Relations, London, Routledge, 2018. 
Such considerations call on IR theory to go back to the road less travelled of encountering the multiverse of relations animating global life. This move demands not only the rejection of the privileging of stability over change in IR's knowledge-production, but also dispensing with the assertion (regardless of whether it is explicit or implicit) that such stability is normatively preferable. Instead of engaging in such relational intellectual travelling, IR theory still refuses to recognize "other" forms of theory-building that fall outside its Eurocentric frame. In other words, thinking beyond the Eurocentric frames of IR urges "us to connect the questions of political possibility with the dynamics and the intransigence of vast domains that are themselves recalcitrant to the purchase of politics" and, at the same time, acts as a provocation "to imagine worlds both before and after us" ${ }^{67}$ Such a move has a palpable relational flavour associated with the convivial, yet dissonant cross-pollination of values, narratives, and practices in the study of global life. This endeavour does not shy away from the struggles, tensions, and inconsistencies of global life. The point here is that IR theorizing becomes a relational process of irruptive translation that brings in dialogue the form and substance of the languages and experiences of diverse and infinitely complex worlds.

These considerations disclose alternate ways of discovering, questioning, and reflecting about existence, normative problems, and the nature and meaning of events. At stake here is the ability to engage other ontologies as a way of learning other ways to observe and encounter the world, ourselves, and the problems that embroil us, and to put such alternatives into a nuanced comparative conversation with more familiar critical political lexicons and procedures inherited from Western/Eurocentric academic scholarship. ${ }^{68}$ In this respect, the ethical verso of relationality is about the cultivation of attentiveness to the emergent, self-organizing, and contingent reality of global life. This move implies that things in global life are not merely interconnected, but that they gain meaning and significance within complex webs of entanglements and encounters with others.

Thus, Brussels and Beijing are learning that for their normative power to be considered legitimate, they themselves are expected to behave in certain ways to earn such recognition. The viability of either the "EU model" or the "China model" is not entirely dependent on the decisions of Brussels' or Beijing's respectively, but contingent on the interpretation of their agency by other actors. In this respect, actors (and their agency) have effects only to the extent that they are in relations with others. Owing to the dynamic nature of such interactions, what passes for world order is not only constantly changing, but demands ongoing commitment to participating in and maintaining relations.

Normative powers are only "partial agents" - that is, in an international environment defined by constant flux, the ability to define the "normal" is subject to ongoing negotiation in which "the parties learn about each other and themselves". ${ }^{69}$ In this setting, recognition emerges as "the core constitutive moment" of international interactions and refers to "the communicative process in the international society of states through which states mutually acknowledge the status and social esteem of other states" ${ }^{70}$ The acknowledgement of such a nascent struggle for recognition suggests that the contestation between normative powers moves beyond their relative capability - i.e., it cannot be captured through the narratives of "struggle for power". In other words, the answer to the

67 Emilian Kavalski and Young Chul Cho, “The European Union in Central Eurasia: Still Looking for Strategy”, Asia Europe Journal, Forthcoming.

68 Kavalski, “Towards a Relational Knowledge-production”, p.166.

69 Paltiel, The Empire's New Clothes, p.206; Emilian Kavalski and Young Chul Cho, "Governing Uncertainty in Turbulent Times", Comparative Sociology, Vol.14, No.3, 2015, p.443.

70 Nel, "Redistribution and Recognition”, p.963. 
question "Who or what exists politically as a normative power?" is "Those actors that are recognized as normative powers". Recognition, in this setting, is indicated by the specific attitudes, dispositions, and behaviour of target states. Owing to the inherent insecurity of the struggle for recognition, international actors attempt to take control over the process of meaning-creation, by anchoring their identity to explicit material practices. ${ }^{71}$ For instance, the EU's desire for recognition is grounded in the practices of the common market and China's - in the government-led model of development. What distinguishes normative powers is their willingness to create and improvise in the context of ongoing and contingent interactions rather than rely on the provision of prescriptive or proscriptive solutions. It has to be acknowledged that such relational framing of normative powers will make the explanation and understanding of IR doubtlessly messy, but it also promises to heal the habits of control, manipulation, and exploitation associated with IR's insistence on the separation between subject and object, knower and known, self and other, mind and matter

Thus, in the complexity of global life, the recognition by others rests on recognition of others. ${ }^{72}$ In this context, the reference to normative power indicates an actor's ability to show consideration for the effects of its actions on others. As suggested, China's respect for the other encourages expectations of reciprocity. It goes beyond the mere acknowledgement of an actor's "equal membership rights" and involves "an appreciation about what is distinct and valuable" about this actor. ${ }^{73}$ The EU's expectation for compliance with its norms appears out of tune with a global life "no longer [guided by] the elimination of inequality, but the avoidance of degradation and disrespect". ${ }^{4}$

But such recognition is both tentative and revocable, and attests to the "constitutive vulnerability" of international actors - especially, normative powers - to "the unpredictable reactions and responses of others". ${ }^{75}$ This suggestion does not deny that the relationship is asymmetrical; yet, the status of the EU and China as normative powers is premised on having others' acknowledgement - i.e., it is a two-way process. The point is that material asymmetries do not translate neatly into relational one. International interactions are volitional and the structure of hierarchy should not be misunderstood as giving one side influence over the other. On the contrary, the very nature of reciprocal obligation belies its constraining power on all participants in a relationship. Thus, the ability to treat others with respect allows normative powers to gain the recognition that creates the permissive environment allowing them to define and redefine the standards of the "normal" in international life. Thus, the international identity of an actor is not just about capabilities, but mostly about recognition - which is both an outcome and a reassertion of an actor's normative power. As such, the myriad entanglements of people, powers, and environments (as well as their complex histories, cultures, and agency) stimulates an awareness of the dynamically-intertwined contingencies through which different paradigms have come to be articulated and assembled.

The study of normative power beyond the Eurocentric frames reveals that IR theorizing is not merely about the provision of knowledge (in the sense of a positivistic measuring exercise); rather, it is about forming than purely informing; it is about the art of living than de-contextual and detached abstract thought; it is about doing ethical considerations in theory and practice. The proposition here

71 Kavalski, “The Struggle for Recognition of Normative Powers”, p.258.

72 Emilian Kavalski, “The Fifth Debate and the Emergence of Complex International Relations Theory”, Cambridge Review of International Affairs, Vol.20, No.3, 2007, p.435-454.

73 Nel, "Redistribution and Recognition”, p.965; Kavalski, “The Guanxi of Relational International Affairs".

74 Axel Honneth, “Recognition or Redistribution?”, Theory, Culture \& Society, Vol.18, No.2/3, 2001, p.43.

75 Kavalski, “The Struggle for Recognition of Normative Powers”, p.259. 
is that the disciplinary mainstream (and particularly its Anglophone variants) has, on the one hand, evaded the need to recognize that there are dynamics which are not only unknown, but probably cannot ever be meaningfully rendered comprehensible, and, on the other hand, has stifled endeavors that can engage in thoughtful deliberation of the discontinuities, unpredictability, and non-linearity of global life. It is in this setting that this study posits that post-Western IR is necessarily contextual, incoherent, and socially-mediated - just like the everyday patterns and practices of the global life it intends to explain and understand. The study of normative power beyond the Eurocentric frames simultaneously amplifies and analyses the intrinsic relationality both of global life and the realms of IR. Such complexification uncovers an IR as a project of disclosure - on the one hand, disclosing worlds and possibilities foreclosed by the Eurocentrism of the discipline; and, on the other hand, disclosing the inextricable and invariable intertwinement between understanding, explanation, practices, and encounters in the study of world affairs. After all, what is IR as a discipline if not the conscious exploration and encounter with the interstitial and relational. Thus, the curious and provocative entanglements with the complexity of global life invoke the pluriverse of possible worlds. 